\title{
The Relationship Between Brand Personality and Customer Service Delivery:Perspectives from Public Universities in Kenya
}

\author{
Kegoro Ongoto Henry \\ Ph.D. Candidate, Department of Business Administration, University of Nairobi, Kenya \\ Box 26495-00100 Nairobi, Kenya \\ Prof. Munywoki Justus \\ P.O Box 30197, GPO, Nairobi, Kenya \\ Prof. Kibera Francis \\ Department of Business Administration School of Business, University of Nairobi \\ P.O Box 30197, GPO, Nairobi, Kenya \\ Dr. Magutu Peterson \\ Department of Management Science School of Business, University of Nairobi \\ P.O Box 30197, GPO, Nairobi, Kenya
}

\begin{abstract}
The main aim of this study was to establish the relationship between brand personality and customer service delivery of public universities in Kenya. The variables of this study were anchored on brand personality and SERVQUAL models. Data was collected using positivist and cross-sectional approaches. Data was obtained from respondents using multi-sampling and random sampling techniques. The total population of the study involved 31 public universities comprising a total of 84,931 respondents. Random sampling method was used to determine the sample from of 15 public universities that comprised of 61,541 respondents from which the sample size of this study was obtained. The ideal sample size of 398 respondents was determined using Israel scientific formula. Selfdeveloped questionnaire comprising closed and open questions was adopted in collecting data. Items of the questionnaire were measured using a Likert scale. Linear mixed effect models were used to analyse data. The findings revealed that brand personality have a significant positive impact on customer service delivery of public universities in Kenya. The overlapping metrics of brand personality which limited the study were minimized by adoption factor analysis method before conducting linear mixed effect tests. The findings imply that managers of public universities can enhance customer service delivery by adoption of brand personality strategy. Further, the findings shed more light to policy makers, marketing practitioners and scholars on how brand personality can be used to enhance customer service delivery. This study is one of the novel studies that has deviated from the conventional approaches of data analysis. Multi-level approach of data analysis facilitated by mixed effect model tests disobeys the Ordinary Least Square statistical assumptions thus revealing the impact of brand personality within and between students of the universities in relation to service delivery.
\end{abstract}

Keywords: Brand Personality, Customer Service Delivery and Public Universities.

DOI: $10.7176 / \mathrm{JMCR} / 75-03$

Publication date: January $31^{\text {st }} 2021$

\section{Background}

Organizations around the world and more specifically institutions of higher learning have continued to appreciate the role of brand personality strategy in enhancing customer service delivery (Giovanni \& Daniela, 2018). With globalization of higher education services, potential customers of higher education services are determined to find a brand that display human qualities (Gary, José, Susan, Melisaa \&Theresa, 2018). Brands that express favoured human qualities such as competence, sophistication, excitement, sincerity and ruggedness are more likely to enhance customer loyalty (Banahene, 2017 \& Chin, 2016). In any service sector, consumers are more likely to identify themselves or associate with brand that exceed their expectations and vice versa (Kapferer, 2010). Consumer connectedness with the brand is purely determined how the organization position the product or its services in the mind of consumer Self-esteem of consumers and identity with the existing or new brand in the marketplace is enhanced by frameworks adopted by organizations to deliver their products and services (Chin, 2016). Homburg, Kuester and Krohmer (2009) suggest that considering the fact that services are intangible, application of brand personality to enhance customer service delivery is considered to be key in the marketing of education services. Customer service delivery is considered to be a function of brand personality from the marketing literature (Keller, 2010). Competition in multiple sectors and more especially in the higher education sector has made institutions of higher learning to rethink on brand personality as an alternative marketing strategy that can facilitate enhanced customer service delivery (Kotler, 2010) 
Brand personality theory advanced by (Aaker, 1997) was used to inform this study. The theory opines that competitiveness of any organization is dependent on five dimensions which involve: brand excitement, sincerity, ruggedness, sophistication and competence. Organizations that invest in brand personality are likely to experience enhanced productivity in terms of market share, profits, customer loyalty and enhanced brand image. This theory was applied in this study based on the logic that, universities can enhance customer service delivery if they emphasize on brand personality strategy. Customer service delivery being the general assessment of services provided by organizations by individual customers (Birori, 2014), standardizing services from one context to another can be a challenging task thus the need for an organization to adopt brand personality strategy in order to manage consumer expectation (Keller, 2010). Perspectives of customer service delivery recommended by Parasuraman, Zeithaml and Berry (1985) are: tangibility, assurance, reliability, empathy and responsiveness. Tangibility perspective is viewed as attributes of physical products associated with services. Assurance of a service is regarded by Kapferer (2010) as the continuous improvement of services provided to customers. Further, service assurance as the maintenance of high level of standards for services delivery to customers. Service reliability is the ability of the organization to deliver services promised to customers on a timely manner. Service empathy is the extent to which customers are given personal attention by service providers in an organization (Kotler, 2010) and service responsiveness is the determination of service provides to surpass customer needs and wants.

Organizations can apply brand personality strategy in managing customer expectations from one context to another (Kapferer, 2010). Perspectives of brand personality that managers in organizations can embrace to enhance customer loyalty involve: brand competence, sophistication, excitement, ruggedness and sincerity. According to Aaker (1997), brand competence is regarded as the capacity of the organization to engage highly skilled, trained, knowledgeable and experienced workers to over a range of services to prospects or existing customers. Brand sophistication is viewed as the capability of the organization to adopt appropriate technology in service delivery or production of goods. It is the extent to which the organization can engage computer literate workers to interact with the systems with an aim of serving customer in a more efficient and effective manner. Brand excitement is termed to be the extent to which an organization can produce services or products that exceed expectations of new and existing customers. Brand ruggedness is defined as superior features expressed by companies producing products and services. Perspectives of ruggedness can be state of the art technology, unique products or services, market share and number and experience of staff. Finally, brand sincerity is described as the capability of the organization to fulfil its promises to customers at the right time without fail (Chin, 2016; Kotler, 2010 \& Aaker, 1997).

For sustainable economic stability, countries are expected to invest in higher education. Universities in any country are considered to be hubs of research, training and education. Universities can be defined as institutions of higher learning created by Acts of parliament to provide education services to its populace (Nganyi et al., 2014). Universities can be categorized to private and public. Private universities are entities formed by private investors but regulated by government agencies with an aim of conforming to the required standards (Magutu et al., 2010). Public universities are entities that are fully created and financed by the government (Inter-University Council for East Africa, 2014). Services provided by both private and public universities are subsided to some extent through higher education loan board funds to facilitate student learning. Equally, both private and public universities are mandated to train student and award them with certificates, diplomas and degrees (Commission for University Education, 2016).

Since independence, Kenya has experienced remarkable developments in the higher education services. Change of the 7-4-2-3 education system to 8-4-4 system not only resulted to universities increasing the number of student enrolment through module II but also accelerated the need for universities to expand infrastructural facilities as well as increase employee capacity to accommodate the larger number of students enrolled (Magutu et al., 2010). Universities have continued to increase in number due to increased demand for education services as well as the population. Many technical colleges have been transformed into full-fledged universities operating under Charters provided by the government (Malechwanzi \& Mbeke, 2016). Quality regulatory commission such as Commission for Higher Education (CHE) has been replaced with Commission for University Education (CUE). The aim of the quality regulatory commission is to ensure that universities established are complying with the set out regulations thus production of highly knowledgeable and skilled graduates to fit in an industries economy (Wahome, \& Gathungu, 2013).

Considering the fact that Kenya is a developing country with an aim of fulfilling Vision 2030 initiatives, investment in higher education is considered to be a driver of economic growth. Despite this notion, public universities in Kenya have been dragging behind in producing graduates who can fit-in the globalized economy thus making service delivery in public universities to be questioned. For decades, public universities in Kenya are producing graduates who are less attractive to local and international employers (FKE,2018). The slow pace of economic developments in Kenya has been attributed to inability of the public universities to improve their services thus resulting to production of well-equipped graduates with diverse knowledge and skills to fit in the globalized economy (Wambui, 2011). This study was inspired by the notion that, new knowledge generated would help 
university managers, policy makers, scholars and practitioners to fully recognize the role of brand personality as an alternative marketing strategy of enhancing customer service delivery in the university context. Similarly, new knowledge generated would also validate existing brand personality theories thus providing a better explanation on how brand personality strategy can be applied to market higher education services.

\section{Research Problem}

Brand personality is recognized as the driver of customer service delivery in different contexts. Organizations that embrace brand personality strategy are associated with improved customer loyalty, increased volume of sales as well as profits (Amel, Ayman, Mohamed \& Alaa, 2018).

Like any other organization, application of brand personality strategy in marketing higher education services is equally recognized the same way it is recognized when marketing tangible products (Malechwanzi \& Mbeke, 2016). With increased demand for higher education services, competitive universities around the world are embracing brand personality strategy with an aim of attracting and retaining customers (Matokho \& Anyieni, 2018). Despite the fact that brand personality strategy has been attributed to enhanced brand performance (Wahome, \& Gathungu, 2013), it is noted that a few studies have been conducted in the university context and more specifically in Kenya. As universities in Kenya continued to experience service delivery challenges, little attention has been paid by researchers to establish how brand personality strategy can be used to influence customer service delivery. Unemployment of university graduates has been attributed to issues of service delivery in public universities (Federation for Kenya Employers, 2018; Kenya National Bureau of Statistics, 2017\& World Bank, 2016). Moreover, customer service delivery in public universities has been compromised by periodical strikes of teaching and non-teaching staff, inadequate funds to support key functions such as capacity development and infrastructural investment (Magutu et al., 2010; Nganyi, Shigogodi \& Owano, 2014).

Ascertaining the link between brand personality and customer service delivery is a field surrounded by controversial findings from researchers. The controversies have been attributed to numerous constraints that range from nature of the product or service, concepts, theories, contexts and methodologies. For instance, a study by Khian et al. (2017) revealed a positive moderating effect of customer satisfaction on the relationship between consumer-based virtual brand personality and brand loyalty among bank customers in Malaysia. Contrary, this study was geared towards establishing the direct link of brand personality on customer service delivery in the university context in Kenya. Brand personality was confirmed to be insignificant on brand performance (Abdulsattar, 2019, Fiona \& John, 2017). Though, the study was limited to Nike products which were tangible contrary to higher education services of the current study. Further, a study by Fiona and John (2017) was confined to higher institutions of learning in the United Kingdom which was a developed country contrary to Kenya which is a developing country.

Even though Amel et al. (2018) revealed a positive association between branding identity, personality, image and communication on educational performance, it is observed that variables of the current study were examined partially without assessing the moderating effect of strategic marketing partnerships and organizational demographics in the relationship. Considering that empirical studies have been conducted in Kenya attempting to examine the link between brand personality and customer service delivery, it is observed that some of them had examined variables of this study partially, focused on tangible produces thus failing to test the direct effect between brand personality and customer service delivery (Mutinda, 2016; Waithaka, 2014 \& Owino, 2013). It can be concluded that from the findings of the studies that, brand personality research in the university context has been understudied for decades thus the need for this study to examine the direct link of brand personality on customer service delivery. It is noted that some of the studies conducted were inclined towards tangible products (Mutinda, 2016 \& Abdulsattar, 2019) thus constraints of generalizing their findings in this study. Subsequently, the current study was unique in its own way by using a multi-level approach of data analysis contrary to previous studies that used a single approach of data analysis (Wahome, \& Gathungu, 2013; Khian et al., 2017; Mutinda, 2016; Waithaka, 2014; Owino, 2013 \& Abdulsattar, 2019)

\section{Research Objective}

The general objective of this study was to evaluate the effect of brand personality on customer service delivery. The specific objective of the study was to determine the effect of brand personality on customer service delivery of public universities in Kenya.

\section{Literature Review}

In the marketing literature, brand personality is viewed as a multifaceted construct which can influence brand performance directly or indirectly (Rutter, 2013). Many studies conducted reveals a significant relationship between brand personality and customers service delivery (Thongthi \& Polyorat, 2015; Anantha \& Abdul Ghani, 2012; \& Rahman, Khan \& Haque, 2012); however, limited studies have evaluated the impact of brand personality, strategic marketing partnerships and organizational demographics on customer service delivery, particularly within 
the university context. Development of a single model that explains the overall customer service delivery experience is affected by the constraints of multiple dimensions and complexity of brand personality construct. Some studies have revealed a linear significant relationship between brand equity and rebranding (Sohini, Rejoice, Norman \& Eugine, 2019); though, a few studies have examined holistically examined the influence of brand personality on customer service delivery in the university context. Studies are yet to be undertaken to clear the controversies between brand personality and customer service delivery from one context to another.

Models of previous studies have provided partial explanations of brand personality (Ewa \& Wawrzyniec, 2019) thus pertinence of this study to unearth the research gaps. Many scholars have found a link between brand personality and brand performance (Chin, 2016; Bijuna et al., 2016; Charraz \& Muhammad, 2014 \& Nashwan, 2015); however, brand personality dimensions are examined partially and explicit model to describe the link between brand personality dimension on customer service delivery from one context to another is yet to be established. Some studies have revealed varied significant links between brand personality dimensions and brand performance (Jayasundara, Ngulube \& Majanja, 2010; Chinomona, Masinge \& Sandada, 2014), however, the studies were limited to different contextual environment such as Sir Lanka, Egypt and South Africa contrary to the context of the current study. Further, the studies did not arrive on a common conclusion concerning a model that can describe brand personality in a more explicit manner in the university context.

A positive and significant relationship was found between brand personality and customer loyalty (Teimouri, Fanae, Jenab, Khoury \& Moslehpour, 2016); nevertheless, the study was confined to tangible products contrary to intangible services of this study. Variations in directions, concepts and magnitude can be revealed if the study is replicated in different contexts with different products or services. Making a conclusion that brand personality can positively influence customer service delivery in the university context the same way it influences performance of tangible products can be misleading. To confirm validity of the results in the measurement of services, a study should be conducted to confirm convergence or divergence of the results from one context to another. Some studies have revealed that customer purchase intentions of products can be influence by brand personality as well as moderated by product involvement (Mutinda, 2016); nevertheless, the study did not test the direct link between brand personality and customer service delivery. Considering that brand personality was applied to measure customer purchase intentions of smart phones in the university context, it is difficult to generalize the findings when measuring customer service delivery in the university context. To address the research gaps, a linear relationship between brand personality and customer service delivery in the university context was tested.

Many scholars have demonstrated that not all dimensions of brand personality that explicitly measure products and services from one context to another (Hsu, 2014 \& Sun et al., 2014). Some dimensions are effectively applicable in the product sector (Mutinda,2016) while other are can be effectively used to describe services (Hsu, 2014). Some studies have measured brand personality using intangible products (Perepelkin \& Zhang, 2011; Hultman et al., 2015; Rashwan et al., 2018; Cleff, Dörr, Vicknair \& Walter, 2013; Vjollca and Shyle, 2015); nevertheless, based on the multi-dimensionality approach of brand personality construct, an explicit model explain on how brand personality can be used to measure customer service delivery in the university context is yet to be established. Some scholars acknowledge scholars should not only apply brand personality to measure products and services but should also reconfigure the constructs of the models to facilitate robust explanation of ideas in the marketing literature (Abdulsattar2019; Ewa \& Wawrzyniec, 2019; Charraz \& Muhammad, 2014; Nashwan, 2015).

Brand personality is considered to be an alternative strategy of enhancing customer service delivery Rutter, 2013; Petruzzellis \& Romanazzi, 2010). Conversely, differences have been reported between brand personality and perceived service quality (Thongthip \& Polyorat, 2015). Organizations that embrace favoured human traits such as brand sophistication, sincerity, ruggedness, excitement and competence are likely to influence customer service delivery and vice versa (Aaaker, 1997; Teimouri et al., 2016; Soni, 2015; Rashwan, Shawky, Ragheb \& Bary, 2018). Some studies have adopted a single approach of data analysis contrary to the multiple approach of the current study (Hsu 2014; Perepelkin \& Zhang, 2011); however, dimensions of brand personality were operationalized differently in different contexts thus the need for further studies to establish a novel framework to explain how brand personality can influence customer service delivery in the university contexts. Given the psychometric approach of evaluating services, studies should seek to modify the brand personality model (Aaker,1997) and SERVQUAL model (Parasuraman et al., 1985) in order to find an explicit model that explain how brand personality can be applied to measure customer service delivery in the university context.

In this paper, the view of customer service delivery is premised on brand personality science, drawing upon service research. At the centric angle of service research, the link between brand personality and how organizations maintain customer service delivery is established. Strong feelings and emotions developed by customers towards the brand are determined by perceptions, attitudes, beliefs and motives (Aaker, 1997). Satisfied customers are easily converted into opinion leaders or brand ambassadors. Organizations that strive to improve existing services or develop new products can enhance customer service delivery (Habibollah \& Zahra, 2013). Whilst, Willems and Swinnen (2011) assert that, for global competitiveness of firms, managers should appreciate the role of brand 
personality. Organizations are likely to attract and retain more customers by embracing brand personality (Habibollah \& Zahra, 2013). Inability of firms to adopt brand personality strategy can result to negative consequences such as reduced market share, profits and lack of customer confidence and trust towards the brand (Hong \& Ha, 2016). For sustainable customers' service delivery in any organization, brand personality is key (Willems \& Swinnen, 2011).

Marketing literature has effectively demonstrated that brand personality is effectively measured from the consumer's view as opposed to the firms' perspective. The level of knowledge experience, exposure, attitudes, beliefs, perceptions are all aspects considered to influence on how customers measure brand personality. Since individuals are not the same, a service can be evaluated differently by different customers (Aaker, 1997). On the other hand, (Kotler, 2010) acknowledges that standardizing services from one context to another is a complex task. Even though brand personality model developed by Aaker (1997) has been extensively applied in social research, little is understood on how its dimensions can be operationalized and conceptualized from within and between contexts (Hsu 2014). In addition, a few studies have examined the impact of brand personality on customer service delivery in the university context in Kenya. Most of the studies are included towards developed countries and brand personality dimensions are partially examined (Petruzzellis \& Romanazzi, 2010).

\section{Conceptual Framework}

Brand personality model (Aaker, 1997) and SERVQUAL model (Parasuraman et al., 1985) were used to inform the conceptual framework shown in Figure 1. The conceptual framework demonstrates the direct link between brand personality on customer service delivery. Brand personality variable is measured using five dimensions which involve: brand sophistication, competence, sincerity, excitement and ruggedness while customer service delivery variable is measured using indicators which involve: reliability, responsiveness, assurance, empathy and tangibles.

\begin{tabular}{|c|c|}
\hline $\begin{array}{l}\text { Brand Personality } \\
\text { - } \quad \text { Brand Sophistication } \\
\text { - } \quad \text { Brand Competence } \\
\text { - } \quad \text { Brand Sincerity } \\
\text { - } \quad \text { Brand Excitement } \\
\text { - } \quad \text { Brand Ruggedness } \\
\text { (Independent Variable) }\end{array}$ & $\begin{array}{l}\text { Customer Service Delivery } \\
\text { - } \text { Reliability } \\
\text { - } \text { Responsiveness } \\
\text { - } \text { Assurance } \\
\text { - } \quad \text { Empathy } \\
\text { - Tangibles } \\
\text { (Dependent Variable) }\end{array}$ \\
\hline
\end{tabular}

Figure 1: Conceptual Framework

Source: Current Researcher

\section{Conceptual Hypothesis}

The research hypothesis that was developed from the conceptual framework as shown in Figure 1 was:

$\mathbf{H}_{01}$ : There is no significant relationship between brand personality on customer service delivery of public universities in Kenya.

\section{Methodology}

Positivist paradigm and cross-sectional research design were used to establish the relationship between brand personality and customer service delivery of public universities in Kenya. The target population of the study consisted of 84,931 respondents from the 31 public universities operating in Kenya while the sample size of the population was obtained from a sample frame of 15 public universities consisting of 61,541 respondents. Israel (2009) formula was applied to calculate the ideal sample size of 398 respondents. The respondents of the study were fourth year undergraduate students who were randomly selected using a multi-stage sampling technique. Self-developed questionnaire comprising both closed and open questions was used to collect data. Likert scale type was preferred for the measurement of the research variables. Data was analysed in three stages. The first step involved descriptive statistics which aimed to determine basic behaviour of data. The second step involved factor analysis method which aimed to reduce the overlapping items used to measure key variables of the study. The third step involved the linear mixed effect (LME) model tests which aimed to test the hypothesis of the study. 
Table 1: Operationalization of Study Variables

\begin{tabular}{|c|c|c|c|c|}
\hline Variable & $\begin{array}{l}\text { Variable } \\
\text { Name }\end{array}$ & Indicators & Rating Measures & $\begin{array}{l}\text { Supporting } \\
\text { Literature }\end{array}$ \\
\hline $\begin{array}{l}\text { Independent } \\
\text { Variable }\end{array}$ & Brand Personality & $\begin{array}{l}\text { Brand Sophistication } \\
\text { Brand Competence } \\
\text { Brand Sincerity } \\
\text { Brand Excitement } \\
\text { Brand Ruggedness }\end{array}$ & $\begin{array}{l}5 \text { point Likert- } \\
\text { type scale }\end{array}$ & 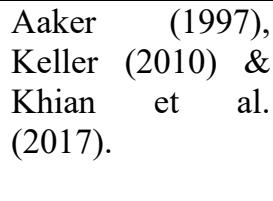 \\
\hline $\begin{array}{l}\text { Dependent } \\
\text { Variable }\end{array}$ & $\begin{array}{ll}\text { Customer Service } \\
\text { Delivery }\end{array}$ & $\begin{array}{l}\text {-Reliability } \\
\text {-Responsiveness } \\
\text {-Assurance } \\
\text {-Empathy and } \\
\text {-Tangibles }\end{array}$ & $\begin{array}{l}5 \text { point Liker-type } \\
\text { scale }\end{array}$ & $\begin{array}{l}\text { Parasuraman et al. } \\
\text { (1985). }\end{array}$ \\
\hline
\end{tabular}

Source: Literature Review

The research objective of this study was tested using linear mixed effect (LME) model tests. The equations expressing the direct effect between brand personality and customer service delivery within and between the universities are depicted as show in equation 1:

$Y_{i j}=\gamma_{0 j}+\beta_{1} X_{i j}+\varepsilon_{i j}$ Equation (1a)

$\gamma_{0 j}=\beta_{0 j}+\mu_{1 j} X_{1 i j}+\mu_{0 j}$

The abbreviations used in the equations are interpreted as follows: Customer service delivery(CSD) as viewed by student $\mathrm{i}$ from university $\mathrm{j}$ is represented by $Y_{i j}$. Brand personality (BP) is represented by, $X_{i j}$ as viewed by student $\mathrm{i}$ from university $\mathrm{j}$. The fixed intercept is represented by $\gamma_{0 j}$. The fixed effect of regression coefficient of brand personality which explains the change caused in customer service delivery because of the unit variation in brand personality at the students' level of analysis. The random intercept is represented by $\beta_{0 j}$. A change in customer service delivery expressed by the random slope of brand personality because of the variation of brand personality across the universities is represented by $\mu_{1 j}$. Factors which accounts for the change in customer service delivery but cannot be described by the linear effect model for both levels are represented by error terms. Error term at level-1 is represented by $\varepsilon$ and error term at level- 2 is reprseented by $\mu_{0 j}$

Table 2: Analytical Interpretation of Data

\begin{tabular}{|c|c|c|c|c|}
\hline Objective & Hypothesis & Analytical Model & $\begin{array}{l}\text { Analysis } \\
\text { Technique }\end{array}$ & Interpretation \\
\hline $\begin{array}{l}\text { Determine the } \\
\text { effect of } \\
\text { brand } \\
\text { personality on } \\
\text { customer } \\
\text { service } \\
\text { delivery of } \\
\text { public } \\
\text { universities in } \\
\text { Kenya. }\end{array}$ & $\begin{array}{l}\mathrm{H}_{01} \text { : Brand } \\
\text { personality } \\
\text { has no } \\
\text { significant } \\
\text { effect } \\
\text { between on } \\
\text { customer } \\
\text { service } \\
\text { delivery of } \\
\text { public } \\
\text { universities in } \\
\text { Kenya. }\end{array}$ & $\begin{array}{l}Y_{i j}=\gamma_{0 j}+\beta_{1} X_{i j}+\varepsilon_{i j} \ldots \ldots \ldots \ldots \ldots . . . . . . . . . . \\
\text { (1a) fixed effects } \\
\gamma_{0 j}=\beta_{0 j}+\mu_{1 j} X_{1 i j}+\mu_{0 j} \ldots . . \text { Eqn }(1 \mathrm{~b}) \\
\text { random effects } \\
\text { Where; Y denotes Customer Service } \\
\text { Delivery, X denotes Brand Personality, } \gamma \\
\text { denotes the fixed Intercept, } \beta_{1} \text { denotes } \\
\text { fixed effect coefficient of X and } \varepsilon \text { denotes } \\
\text { the fixed effect error term } \mu_{0 j} \text { and } \mu_{1 j}\end{array}$ & $\begin{array}{l}\text { Mixed effect } \\
\text { model } \\
\text { REML }\end{array}$ & $\begin{array}{l}\text { Wald Chi- } \\
\text { square was used } \\
\text { to evaluate } \\
\text { overall } \\
\text { significance of } \\
\text { the fixed effect } \\
\text { model. } \\
\text { Z-tests was used } \\
\text { to establish } \\
\text { significance of } \\
\text { the predictor } \\
\text { variable at level- } \\
1 \\
\text { LR test was } \\
\text { used to ascertain } \\
\text { the significance } \\
\text { of brand } \\
\text { personality as } \\
\text { both level-2 } \\
\text { random } \\
\text { covariate }\end{array}$ \\
\hline
\end{tabular}

Source: Current Researcher 


\section{Data Analysis, Findings and Discussion \\ 8.1 Response Rate}

Out of the 398 questionnaires administered to four year undergraduate students of public universities in Kenya, only 314 questionnaires were full filled and returned by respondents. The response rate for this study was $80 \%(314$ questionnaires out of 398) while $20 \%$ represented incomplete or unreturned questionnaires. Missing data cases were managed by using multiple imputation technique was used. The response rate for this study was considered adequate as recommended by (Guest, 2010) who assert that any response rate above $50 \%$ is assumed to be appropriate for scientific studies.

\subsection{Brand Personality and Customer service delivery}

This section describes the relationship between brand personality dimensions on customer service delivery. The brand personality dimensions which were used to measure customer service delivery in the university involve: brand sophistication, competence, sincerity, excitement and ruggedness as described below.

\subsubsection{Brand Sophistication}

The findings of this study revealed a positive and significant impact of brand personality on customer service delivery in the university context. Brand sophistication in the university context in Kenya was measured using the following aspects: ability of the university to have a reliable internets available all the time to students, automated library services, ability of the lecturers to use laptops and computers to facilitate lectures, ability of the students to access the university system thereby accessing financial information, book accommodation rooms and download class timetables. Further, sophistication in the university context was evaluated based on the level to which universities maintained security by using modern surveillance systems such as closed-circuit television (CCTV) cameras. The findings of this study are supported by Thongthip and Polyorat (2015) who concluded that brand sophistication had a strong significant impact on customer service delivery.

\subsubsection{Brand Competence}

Customer service was found to be positively influenced by brand competence. Brand competence in the university context was measured using variety of academic programs provided, professionalism among teaching and nonteaching staff, good relations between staff and students, ability of the university to remain top in academic ranking and the experience of staff to exceed customer expectations. The findings are in line with that of Nashwan (2015) and Yasin et al. (2013) who acknowledge that customer service delivery is a function of brand competence. The authors concluded that, organizations committed in developing human capital are likely to enhance brand performance and vice versa.

\subsubsection{Brand Sincerity}

Brand sincerity was found to influence customer service delivery positively. Brand sincerity in the university context was measured based on the student delight. Availability of entertainment services in the university, recognition of student leadership by university management, fulfilment of promises to students by university management, ability of the students to complete their studies within the specified period and ability of the students to perform well in academics were all aspects said to positively influence customer service delivery. This position was confirmed by Charraz et al. (2014) who discovered that brand sincerity was one of the fundamental dimension of brand personality that enhanced customer loyalty.

\subsubsection{Brand Ruggedness}

Brand ruggedness was established to have a significant impact on customer service delivery in the university context. Customer service delivery in the university context was positively influenced by the capacity of the university to offer a variety of academic programs, have adequate number of staff, infrastructural facilities such as lecture halls, hostels and playgrounds. Further, it was revealed that brand ruggedness was demonstrated in the university context by the university attracting a large number of local and international students as well as remaining the most preferred brand among the competitors. Even if brand ruggedness was considered to be well explained by tangible products, to a larger extent students were attributing services with tangible products. A similar position was held by Waithaka (2014), Nima et al. (2012) and Tho et al. (2016) who concluded that superiority of any brand was dependent on the level of physical investments. 
Table 3: Fixed Effects of Brand personality on Customer Service Delivery

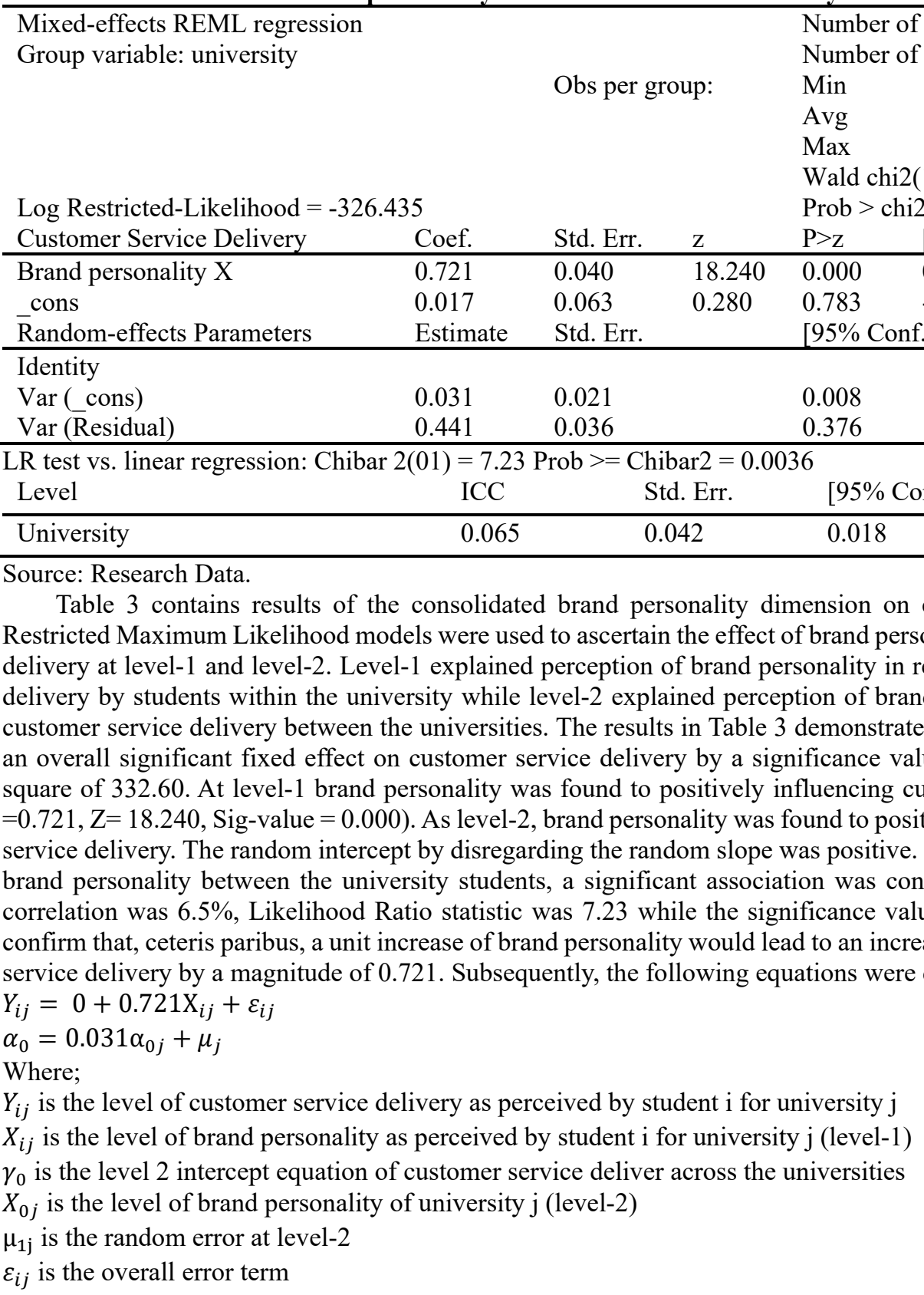

\subsection{Random Effects of Brand Personality on Customer Service Delivery between the Universities}

To ascertain the effect of brand personality on customer service delivery between the universities (level-2), linear mixed effect (LME) fitted to Restricted Maximum Likelihood models and random covariate were revealed to be positive because of brand personality

Table 4: Random Effects of Brand Personality on Customer Service Delivery between Universities

\begin{tabular}{|c|c|c|c|c|c|c|}
\hline \multirow{2}{*}{\multicolumn{4}{|c|}{$\begin{array}{l}\text { Likelihood-Ratio Test } \\
\text { (Assumption: M1 nested in M2) }\end{array}$}} & \multirow{2}{*}{$\begin{array}{l}\text { LR chi2 (1) } \\
\text { Prob > chi2 }\end{array}$} & $=$ & 6.31 \\
\hline & & & & & $=$ & 0.012 \\
\hline \multicolumn{7}{|c|}{ Akaike's information criterion and Bayesian information criterion } \\
\hline Model & Obs & 11(null) & $11($ model $)$ & df & AIC & $\mathrm{BIC}$ \\
\hline M1 - me no random slopes & 314 & & -326.435 & 4 & 660.871 & 675.868 \\
\hline M2 - me random slopes & 314 & & -323.280 & 5 & 656.560 & 675.307 \\
\hline
\end{tabular}

Source: Research Data.

Results illustrated in Table 4, indicated that there existed a positive significant link between brand personality and customer service delivery between the universities. The Likelihood Ratio statistic was 6.31 and significance value was 0.012 . Further, model-1 fitted in model- 2 a positive link was confirmed between brand personality and 
customer service delivery through a random slope which was positive. Using Bayesian Information Criterion (BIC), model-2 $(\mathrm{BIC}=675.305)$ was less than model-1 (675.868), indicating a significant improvement of model-2 which is considered to be a superior model.

\subsection{Hypothesis Testing}

The aim of this study was to ascertain the relationship between brand personality and customer service delivery of public universities in Kenya. The following hypothesis was advanced from literature review:

Hypothesis01: Brand personality has no significant influence on customer service delivery of public universities in Kenya.

The direct effect of brand personality on customer service delivery was determined by using

Mixed effect models fitted nested to Restricted Maximum Likelihood models. At level-1 (within the university) and level-2 (between the universities), the results revealed a positive significant impact of brand personality on customer service delivery. A synopsis of the results is provided in Table 5.

Table 5: Mixed Effects of Brand Personality on Customer Service Delivery

\begin{tabular}{llll}
\hline Mixed-effects REML regression & Number of obs & $=314$ \\
Group variable: university & & Number of groups & $=12$ \\
& Obs per group: & Min & 18 \\
& & $=26.2$ \\
& Avg & $=49$ \\
Log Restricted-Likelihood $=-323.279$ & Max & $=134.25$ \\
& & Wald chi2(1) & $=0.000$
\end{tabular}

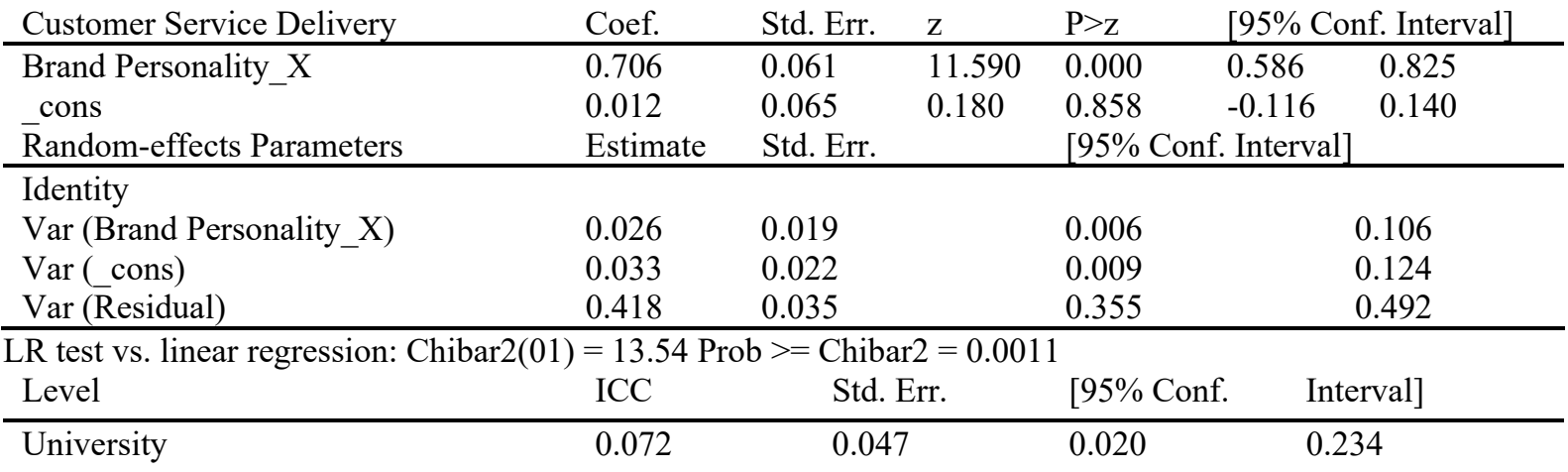

Source: Primary Data.

As shown in Table 5, the mixed effect component model of brand personality had a significant positive impact on customer service delivery. At both level-1 and Level-2, the p-value was less than 0.05 and Chi-square was 134.25. At level-1 (within the university) brand persaolity was found to influence customer service delivery positively. The $\beta$ was $0.706, Z$ was 11.590 and significance value was 0.000 . At level-2 (between the universities), a positive link was also confirmed. The random intercept and slope of brand personality was confirmed to be positive. ( $\mathrm{ICC}=7.2 \%, \mathrm{LR}=13.54$, $\mathrm{Sig}=0.0011$ ). The results in Table 5 confirm that, ceteris paribus, a unit increase of brand personality will result to an increase on the level of customer service delivery in the university context by a magnitude of 0.706 . Considering the findings of this study, the null hypothesis was disregarded and a conclusion was arrived that brand personality has a significant influence on customer service delivery of public universities in Kenya. Conversely, the following equations were created from the model:

$Y_{i j}=0+0.706 \mathrm{X}_{i j}+\varepsilon_{i j}$

$\alpha_{0}=0.033 \alpha_{0 j}+0.026 X_{0 j}+\mu_{j}$

\section{Summary of Research Findings}

The research objective of this study was to determine the effect of brand personality on customer service delivery of public universities in Kenya. The results indicated a significant positive link between brand personality and customer service delivery. A synopsis of the results is illustrated in Table 6. 
Table 6: Summary of Research Objective, Hypothesis and Conclusions

\begin{tabular}{|c|c|c|c|c|c|}
\hline Objective & Hypothesis & $\begin{array}{l}\text { Test } \\
\text { Criteria }\end{array}$ & Statistic & P-value & Conclusion \\
\hline $\begin{array}{l}\text { Determine the effect } \\
\text { of brand personality } \\
\text { on customer service } \\
\text { delivery of public } \\
\text { universities in Kenya. }\end{array}$ & $\begin{array}{l}\mathrm{H}_{01} \text { Brand personality } \\
\text { has no significant } \\
\text { influence on customer } \\
\text { service delivery of } \\
\text { public universities in } \\
\text { Kenya. }\end{array}$ & $\begin{array}{l}\text { Reject } \mathrm{H}_{0} \text { if } \\
\text { the } \mathrm{P} \text {-value } \\
\text { of the } \\
\text { coefficients } \\
\text { is less than } \\
0.05\end{array}$ & $\begin{array}{l}\text { Random } \\
\text { effect L.R } \\
\chi^{2}=6.31\end{array}$ & 0.012 & $\begin{array}{l}\mathrm{H}_{01} \text { was rejected and a } \\
\text { conclusion drawn that } \\
\text { brand personality has a } \\
\text { significant influence } \\
\text { on customer service } \\
\text { delivery of public } \\
\text { universities in Kenya. }\end{array}$ \\
\hline
\end{tabular}

\section{Source: Primary Data}

The Implication: The findings of this study suggest that brand personality is inevitable in the university context. For enhanced customer service delivery, university managers should emphasize on brand personality if they want to enhance brand performance. Adoption of technological initiatives such as automation of library, finance, teaching and security services will enhance customer service delivery in the university context. Further, providing internet services would also influence customer loyalty. Training of the staff in the university context would not only promote employee personal development but also enhanced customer service delivery. Time management and professionalism among the university staff are all aspects that can influence customer service delivery. For enhanced customer service delivery, fulfilling promises, good leadership, reliable information and good reputation of the university are aspects that promote customer service delivery. In addition, satisfactory library, teaching and security services can enhance customer service delivery. Equally, staff punctuality and student rewards and prompt services can as well improve customer service delivery. The capacity of the university to introduce new academic courses, invest in technology and infrastructural facilities can as well improve customer service delivery within and between the universities. Universities with adequate number of hostels, lecture halls, employees and appropriate technology are likely to attract and retain more students. This position is supported by Rashwan et al. (2018) who concluded that brand personality strategy is a strong predictor of customer service delivery in any organization if effectively embraced.

\section{Discussion of Results}

The model adopted in this study effectively demonstrate how brand personality can influence customer service delivery in the university context. Even though other scholars have revealed that brand personality can positively influence customer service delivery from one context to another (Sanjay, 2015; Vjollca \& Shyle, 2015); it is revealed that an explicit model is yet to be established to explain how brand personality strategy can influence customer service delivery from one context to another. Constraints of conceptualizing dimensions of brand personality are evident from in in different contexts thus the need to revise measurement items of each dimension for validity of the model from one context to another (Petruzzellis \& Romanazzi, 2010). Many scholars have indicted a significant link between brand personality and customer service delivery (Habibollah \& Zahra, 2013; Malechwanzi \& Mbeke, 2016); though, it is observed from the studies that each study was confined to different contexts and different category of respondents were used thus making the results of this study non-generalizable in the current study. From the studies, it is observed that there exist varied variations of individual predictor variables in relation to customer service delivery. In this regard, the study recommends studies to be conducted to investigate the effect of individual brand personality variable on the customer service delivery in different contexts. Based on the psychoanalytic approach of measuring brand personality construct, it is difficult to ascertain its universality from context to context. Many studies had used data analysis methods which obeyed the Ordinary Least Square assumptions contrary to the methodology adopted by this study (Owino, 2013; Saghier \&Nathan, 2013); nevertheless, this was a few of the studies that adopted a robust methodology which examined the perception of brand personality in relation to customer service delivery within and between the students of public universities in Kenya unlike the previous studies which adopted a single approach (Bijuna et al., 2016; Charraz \& Muhammad, 2014). This study fills the missing link in marketing literature by revealing how brand dimensions of brand personality can holistically have applied in the university context to enhance customer service delivery (Perepelkin \& Zhang, 2011). Even though individual dimensions of brand personality were found to have varied significant impact on customer service delivery, it can be deduced that emphasize on brand personality in the university context is the driver of university competitiveness (Hong \& Ha, 2016).

\section{Conclusion}

The findings of this study demonstrate that customer service delivery is positively influenced by customer service 
delivery in the university context. The findings offer in-depth understanding to marketing management practitioners, policy makers, scholars and researchers on how brand personality can be used to improve customer service delivery in the university context. The findings depict that, four universities to achieve global competitiveness in the higher education sector from one country to another, brand personality cannot be undermined. Investment in brand personality dimensions holistically would strongly improve customer service delivery in the university context. Despite existence of models that partially explain the effect of brand personality on customer service delivery in the university context, it is pertinent for future researchers reconfigure the models in order to advance new knowledge as well as improve the existing models that try to describe how brand personality strategy can be used to improve customer service delivery in the university setting.

\subsection{Contributions to Theory and Policy}

The current study provides new knowledge to existing body of knowledge by validating brand personality model. This is one of the limited studies that demonstrated that customer service delivery in the university context can be enhanced by consolidated brand personality dimensions regardless the variations of each dimension on customer service delivery. The results of this study contributes to literature on how brand personality strategy can be applied to market higher education services in developing countries. Considering that most of the studies on brand personality are skewed towards developed countries, this study is of great importance to university managers and policy makers in developing countries and especially in Kenya. The findings would help policy makers in the higher education sector to appreciate the role of brand personality on influencing customer service delivery. New insights would be developed by policy makers embedded on brand personality principles. Other players in the higher education sector such as United Nations would benefit from the findings of this study thus leading to development, execution and evaluation of policies geared towards maintaining high standards of customer service delivery in the higher education service sector.

\subsection{Contributions to Marketing Management Practice}

The current study has gone beyond the ordinary approach of indicating on how brand personality directly influence customer service delivery. The study contributes to new knowledge in marketing literature by demonstrating the impact of brand personality on customer service delivery within and between the universities. University managers would use the information of this study to improve customer service delivery. Appreciation of brand personality dimensions by university managers in marketing higher education services would result to improved customer service delivery in terms of student attraction and attention. For global competiveness of universities in the turbulent marketing environment, recognition of the individual dimensions of brand personality which involve: brand sophistication, competence, excitement, sincerity and ruggedness is key. Universities would only attract a larger number of students if they embrace brand personality strategy.

\section{Recommendations}

A significant relationship was established between brand personality and customer service delivery. The findings of this study demonstrate that brand personality is a predominant factor of customer service delivery in the university context. Apart from the academic contribution of this study in marketing literature, it will help university managers to prioritize on brand personality when marketing higher education services. Failure to embrace brand personality would result to non-competitiveness of universities in terms of customer service delivery. Other than studies which have revealed an indirect link of brand personality on customer service delivery, it is confirmed by this study that, university managers should be in a position to recognize brand personality dimensions as precursors that positively explains customer service delivery in the university context.

\section{Limitations of the Study}

Generalizing findings of this study in other sectors can be misleading to readers in developing and developed countries. Therefore, it is important for future studies to collect data from different sectors to facilitate generalizability of the results. Kenya being a developing country with diversified culture, researchers in both developing and developed countries should take into account aspects when replicating this study in other fields. Reconfiguration of the brand personality model would result to a more explicit and robust model to explain how brand personality strategy can effectively improve customer service delivery in the university context. Exploratory paradigm and longitudinal research design are recommended for future studies contrary to positivist paradigm and cross-sectional research design that rely on existing theories as well as fail to assess the trend of events over a given period of time.

\section{Future Research Frontiers}

Investigating the direct link between brand personality and customer service delivery is considered to limit the results of this study. In this regard, the current study recommends that future studies should relook at investing the 
mediating role of strategic marketing linkages on the relationship between brand personality and customer service delivery. Further studies should seek to adopt more explicit data analysis methods such as Structure Equation Modelling(SEM) to ascertain the effect of brand personality on customer service delivery using a single approach contrary to multi-level approach of the current study. Examining the effect of individual brand personality dimensions on customer service delivery would result to generation of an explicit model that describes the impact of brand personality on customer service delivery in the university context. Comparative studies between East African countries are proposed.

\section{References}

Aaker, D., \& Jennifer, L. (1997). Dimensions of Brand Personality. Journal of Marketing Research, 34 (3), $347-$ 56.

Abdulsattar, A. A. (2019). Brand personality dimensions of Nike sportswear. Journal of Business and Retail Management Research (JBRMR), 13 (4), 1-11

Amel, R., Ayman, S., Mohamed, A. R., \& Alaa A. B. (2018). The Role of Branding on Educational Performance in the Egyptian Private Universities. Open Access Library Journal, 5 (1) 1-14.

Birori, O. W. (2014). Internal Customer Satisfaction Assessment in the Public Sector: A Case Study of Fleet Management Services Delivery. International Journal of Recent Research in Commerce Economics and Management, 1(2), 12-28.

Bijuna, C. Mohan \& A. H. Sequeira (2016). The Impact of Customer-based Brand Equity on the Operational Performance of FMCG Companies in India. IIMB Management Review 28, 13-19.

Banahene, S. (2017). The Impact of Brand Personality and Students' Self-Concept on Brand Engagement. International Journal of Business and Social Research. 7, (12), 176-189

Charraz, O., \& Muhammad, S., R. (2014). Investigation of the Relationship of Brand Personality, Subjective Norm and Perceived Control on Consumers' Purchase Intention of Organic Fast Food; Modern Applied Science, 8(3), 2014.

Chin-Tsu C. (2016). The Investigation on Brand Image of University Education and Students' Word-of-Mouth Behaviour. Canadian Center of Science and Education, 6 (4), 1-11.

Cleff, T., Dörr, S., Vicknair, A., Walter, N. (2013). Brand experience. How it relates to brand personality, Consumer Satisfaction and Consumer loyalty. An Empirical analysis of the Adidas Brand. Pforzheim University and ZEW Centre for European Economic Research, Mannheim, Federal Republic of Germany

Commission for University Education (CUE). (2016, December 14). Annual Report. Retrieved from http://www.cue.or.ke.

Commission for University Education Report (CUE) (2018). List of Chartered Universities in Kenya. Retrieved from http://www.cue.or.ke.

Ewa, G. \& Wawrzyniec. R. (2019). City Brand Personality Projected by Municipalities from Central and Eastern Europe Countries-A Comparison of Facebook Usage. Sustainability, 11, 5440; doi:10.3390/su11195440

Gary, D., José, I., R., M., Susan, W., Melisa, M. \& Theresa, L. (2018). Brand personality: Theory and Dimensionality. Journal of Product \& Brand Management, 27 (2), 115-127.

Giovanni, S. \& Daniela, C. (2018). Managing Strategic Partnerships with Universities in Innovation Ecosystems. University of Basilicata, Italy. Journal of Open Innovation, Technology, Market and Complexity, 4 (25), 113.

Guest, G. (2012). Applied thematic analysis. Thousand Oaks, California: Sage. P. 11

Habibollah, D. \& Zahra, A. (2013). The Moderating Effects of Product Involvement on Determinants of Brand Equity on Iranian Young Consumers' viewpoint. Technical Journal of Engineering and Applied Sciences Journal, 3 (22), 15-30.

Homburg, C., Kuester, S. \& Krohmer, H. (2009). Marketing Management, a contemporary perspective. London: McGraw Hill.

Hultman, M., Dionysis, S. \& Oghazi, P. (2015). Achieving Tourist Loyalty Through Destination Personality, Satisfaction, And Identification. Journal of Business Research, 68 (11), 2227-2231.

Hsu, C. H. C. (2014). Brand Evaluation of Foreign versus Domestic Luxury Hotels by Chinese Travelers. Journal of China Tourism Research, 10(1), 35-50.

Israel, G. D. (2009). Determining Sample Size, Institute of Food and Agricultural Sciences. Florida: University of Florida.

Jayasundara, C., Ngulube, P. \& Majanja, M. K. (2010). Using Focus Groups to Investigate Service Quality Determinants for Customer Satisfaction in Selected University Libraries in Sri Lanka. South African Journal of Libraries and Information Science, 76 (2), 118-127.

Kapferer, J. (2010). The New Strategic Brand Management: Creating and Sustaining Brand Equity Long Term, 4th Edition. London: Kogan Page.

Keller, K. L. (2010). Brand Equity Management in a Multichannel, Multimedia Retail Environment. Special Issue, 
Journal of Interactive Marketing, 24 (2), 58-70.

Khian, S. O., Bang, N., S. \& Faridah, S. A. (2017). Consumer-based Virtual Brand Personality (CBVBP), Customer Satisfaction and Brand Loyalty in the Online Banking Industry. International Journal of Bank Marketing, 35(3), 370-390.

Kotler, P. (2010). Marketing Management (12th Ed.). Upper Saddle River, NJ: Pearson Prentice Hall

Magutu, O.P., Mbeche, I. M., Bitange N.R., Onserio N, Nyaanga, R. O. \& Ogoro O. T. (2010). Quality management practices in Kenyan educational institutions: the case of the University of Nairobi. African Journal of Business \& Management (AJBUMA). Retrieved from http://www.ajbuma.or.ke/

Malechwanzi, J. M \& Mbeke, C. (2016). Policies of Access and the Quality of Higher Education in China and Kenya: A comparative Study. Cogent Education, 3 (1), 1-56.

Matokho, K. M. \& Anyieni, A.G. (2018). Strategic Partnerships and Performance of Listed Commercial Banks in Kenya. International Journal of Contemporary Aspects in Strategic Management (IJCASM), 2 (1), 1-13

Mutinda, J. (2016). The Influence of Brand Personality on Customer Purchase Decision of Smartphone in Selected Public University Campuses in Nairobi CBD, Kenya. Published PhD Thesis. Kenyatta University. Kenyatta University. Retrieved from Ir-library.ku.ac.ke.

Nashwan, M. A. S. (2015). How does Marketing Strategy Influence Firm Performance? Implementation of Marketing Strategy for Firm Success. International Journal of Innovation and Economic Development, 1(3), 7-15.

Nganyi, J. E., Shigogodi, J. M. \& Owano, A. (2014). The Effectiveness of Performance Contracting in Service Delivery in Public Universities in Kenya. International Journal of Academic Research in Business and Social Sciences, 4 (10), 433-441.

Owino, O. E. (2013). The Influence of Service Quality and Corporate Image on Customer Satisfaction among University Students in Kenya. Published PhD Thesis. University of Nairobi. Retrieved from http://www.google scholar.

Parasuraman, A., Zeithaml, V. A. \& Berry, L. L. (1985). A conceptual model of service quality and its implications for future research. Journal of Marketing, 49 (4), 41-50.

Perepelkin, J. \& Zhang, D. D. (2011). Brand Personality and Customer Trust in Community Pharmacies. International Journal of Pharmaceutical and Healthcare Marketing, 5 (3), 175-193

Petruzzellis, L. \& Romanazzi, S., (2010). Educational Value: How Students Choose University: Evidence from an Italian university. International Journal of Educational Management, 24 (2), 139-158.

Rutter, N.R. (2013). Personality and Consistency between Marketing Channels on Performance within the UK Higher Education Sector. PhD Thesis. University of Easy Anglia, United Kingdom.

Sanjay, S. S. (2015). Service Quality, Student Satisfaction and Brand Equity: A Case Study of Select South African Universities. Doctoral Thesis. University of Cape Town

Sohini, N., Rejoice, T. M. \& Norman C. \& Eugine, T. M. (2019). The impact of corporate rebranding on brand equity and firm performance. Journal of Business and Retail Management Research (JBRMR), 13 (4), 2-11

Sun, X., Wnag, P., Lepp, A. \& Robertson, L. (2014). Symbolic Consumption and Brand Choice: Chinas Youth Hostels for the International Travel Market. Journal of China Tourism Research, 10(1), 51-68.

Teimouri, H., Fanae, N, Jenab, K. Khoury, S. \& Moslehpour, S. (2016). Relationship between Brand Personality and Customer Loyalty: A Case Study of Samsung Mobile Phone. International Journal of Business and Management, 11 (2), 1-16

Tho, N. D., Trang, N. M., \& Olsen, S. O. (2016). Brand personality appeal, brand relationship quality and WOM transmission: a study of consumer markets in Vietnam. Asia Pacific Business Review, 22(2), 307-324. doi: $10.1080 / 13602381.2015 .1076655$

Thuo, J. K. (2010), The influence of customer relationship management practices on the performance of commercial banks in Kenya. PhD Thesis. University of Nairobi, Kenya. Retrieved from http://www.google scholar.

Vjollca, H. \& Shyle, I. (2015). The Image and Perceived Quality of Universities as Important Dimensions for Building University Brand Equity-Case Study Involving Albanian Students. EJSER European Journal of Social Sciences Education and Research Articles, 3(9), 1-47.

Wahome, E., W. \& Gathungu J. J. W. (2013). Brand Personality and the Evolution of Destination During the Colonial Period in Kenya. Thought and Practice: A Journal of the Philosophical Association of Kenya New Series, 5 (1), 91-119

Waithaka, T., B. (2014). Corporate Identity Management Practices, Organizational Characteristics, Corporate Image and Brand Performance of Kenyan Universities. Published PhD Thesis. University of Nairobi. Retrieved from http://www.google scholar.

Wambui, K.S. (2011). Comparative Analysis of Business Students Perception of Service Quality Offered in Kenyan Universities. International Journal of Business Administration, 1(3), 1-19

Willems, K., \& Swinnen, G. (2011). Am I cheap? Testing the role of store personality and self-congruity in 
discount retailing. The International Review of Retail, Distribution and Consumer Research, 21, 513-539.

Yasin, B., Jamotainte, K. \& Salami, M. A. K. (2013). The Relationship between Hotel Brand Personality and Customer Loyalty. Journal of Tourismology, 3 (1), 1-16. 